\title{
Decision Making Model for Online Music Service Users
}

\author{
Ayako Hiramatsu, Takahiro Yamasaki, Kazuo Nose \\ Osaka Sangyo University, \\ 3-1-1 Nakagaito, Daito, Osaka 574-8530, Japan \\ ayako@ise.osaka-sandai.ac.jp, takahiro@eic.osaka-sandai.ac.jp, \\ nose@ise.osaka-sandai.ac.jp
}

\begin{abstract}
This paper describes a consumer behavior model for online shopping, especially online music services, because they are the most popular online shopping service in Japan. Based on Howard's consumer decision model, questionnaires about decision making for online music services were given to 282 students. The questionnaire results show that almost $90 \%$ of respondents have downloaded from online music services, and high school students use such services slightly more than university students. This paper analyzes the questionnaire results by structure equation modeling and examines the relationships between the factors in Howard's model.
\end{abstract}

\section{Introduction}

Internet penetration in Japan is remarkable. In 2006 its penetration rate was $68.5 \%$, and the number of Internet users was estimated at 87.54 million (White paper 2007). With the Internet's diffusion, the popularity of e-shopping continues to increase. $63.7 \%$ of all Internet users have been using e-shopping for more than two years (Internet Association Japan 2005, 2006), and these numbers are still growing. For marketing, understanding the behavior of e-shopping users is crucial.

To understand consumer behavior, user models are often constructed by analyzing the behavior data of users. Concerning Internet users, there have been some researches about online game models (Hsu and Lu 2004) and e-shopping users (Shih 2004) based on the Technology Acceptance Model (TAM) (Liu 2007). Farag et al. also researched a model that analyzed relationships between e-shops and real shops

Please use the following format when citing this chapter:

Hiramatsu, A., Yamasaki, T., Nose, K., 2008, in IFIP International Federation for Information Processing, Volume 286; Towards Sustainable Society on Ubiquitous Networks, eds. Oya, M., Uda, R., Yasunobu, C., (Boston: Springer), pp. 15-25. 
(2007). Moreover, Watanabe and Iwasaki analyzed why consumers buy PCs through the Internet (2007). However, decision making processes based on various factors and the relationship between them have not been analyzed much, due to such difficulties as direct observation and analysis of the subjective conditions of users.

Our research aims to understand how consumers make e-shopping decisions. Consumer behaviors for real shops (Evans et al. 2006) were researched. Based on Howard's famous consumer decision model (1989), we examined decision making processes in online shopping. The target of this analysis was narrowed to online music services, which are the most popular online shopping service. Questionnaires about decision making for online music services were done with Japanese consumers. The questionnaire results were analyzed by structure equation modeling (Schumacker and Loman 2004) (Kline 2005) to examine the relationships between the factors in Howard's model.

\section{Decision Making Process of Consumers}

The Howard-Sheth buying behavior model presented in 1969 is one important model that explains consumer decision making. It explains the complexity of the consumer decision making process for incomplete information with an S-O-R paradigm that consists of three components: stimulus-organism-response. In this model, consumers are motivated by perceiving a stimulus, and then they shift to purchase after composing concepts to learn purchases. Furthermore, it is hypothesized that the problem is simplified as learning continues. As a result of experimental researches based on this model, Howard proposed the simple consumer decision model shown in Figure 1.

This simple consumer decision model is comprised of six interrelated components, as shown in Figure 1: information $(\mathrm{F})$, brand recognition $(\mathrm{B})$, attitude toward the brand $(\mathrm{A})$, confidence in judging the brand $(\mathrm{C})$, intention $(\mathrm{I})$, and purchase $(\mathrm{P})$. The three central components $(\mathrm{B}, \mathrm{A}$, and $\mathrm{C})$ comprise the buyer's brand image and the $\mathrm{ABCs}$ of consumer behavior.

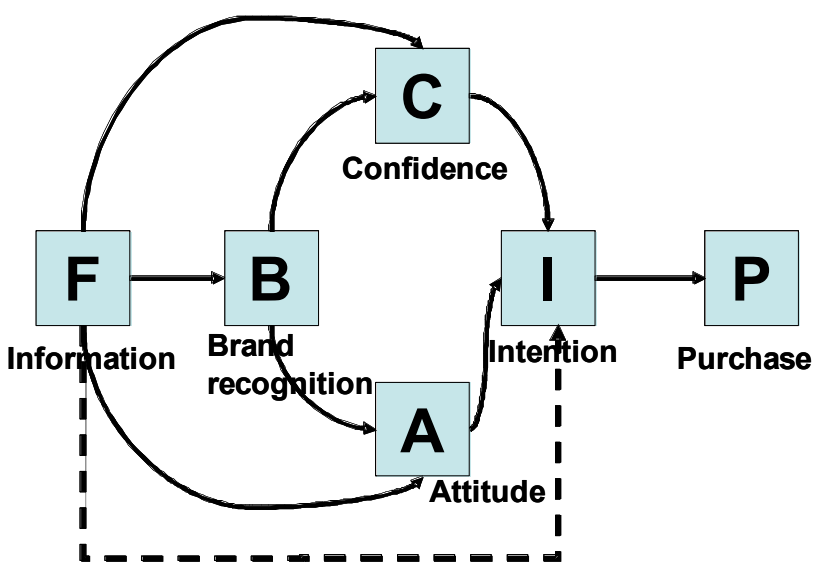

Figure1: Howard's consumer decision model modified for routine problem solving 
"Information" $(\mathrm{F})$ is what is received and stored. The perception is stored, not the stimulus. "Brand recognition" (B) reflects the extent to which the consumer knows enough about the brand to distinguish it from others. "Confidence" (C) is the consumer's degree of certainty that his/her evaluative judgment of a brand, whether favorable or unfavorable, is correct. "Attitude" (A), the second part of brand image, is the extent to which consumers expect the brand to satisfy their particular needs. "Intention" (I) is a mental state that reflects the consumer's plan to buy a specified number of units of a particular brand in a specified time period. "Purchase" (P) shows whether the consumer really does buy the brand. The influence from "information" (F) to "intention" (I) is connected by a dotted line. This arrow is added in routine problem solving cases when consumers repeatedly buy a low-price or a daily product.

\section{Analysis Target}

\subsection{Online Music Service}

With annual growth of about $2 \%$ since 2003 , the size of the visual contents market was estimated in 2005 at approximately 11.3 trillion yen (about $\$ 0.1$ trillion), broken down as follows: visual contents/5.3 trillion yen, audio contents/1.0 trillion, and text contents/5.0 trillion (White paper, 2007). Moreover, the music or game contents market has especially expanded. The usage rate of musical contents is $10.9 \%$, which is the highest among such various contents as visual contents, audio contents, and text contents, of contents by Internet with PCs. Even using contents through mobile Internet, the usage rate of musical ring tones is the highest with $15.6 \%$ and the rate of downloading songs is $14.0 \%$, which is second. Based on this present condition, we chose online music services as our research subject for online shopping through Internet.

\subsection{Survey Items}

To adapt Howard's model to online music services, we considered the following survey items. Channels for acquiring information about online music services are considered communication among friends and families, information from such media as television, radio, and magazines, and such Internet sources as e-mails and web pages. "Brand recognition" corresponds to musicians and online music service providers. For "Confidence", we considered confidence in artists and providers. "Attitude" items include sound quality, price, payment methods, data size, and outtakes or live versions. "Intention" included consumer's income, popularity, season, and advertising campaign. "Purchase" shows whether consumers really buy the music. This experiment examined the degree of experience with online music services. 


\section{Questionnaire Survey}

\subsection{Survey Condition}

The questionnaires asked participants to indicate their degree of agreement with the above items based on a five-point scale: 5-strongly agree, 4-agree, 3-neutral, 2disagree, and 1-strongly disagree. The question details are shown in the appendix. 282 consumers (164 university students, 106 high school students, and 12 others) answered the questionnaires.

Table1: Results of download medium

\begin{tabular}{|l||c|c|c|}
\hline & All & $\begin{array}{c}\text { High school } \\
\text { students }\end{array}$ & $\begin{array}{c}\text { University } \\
\text { students }\end{array}$ \\
\hline \hline Mobile phone & $44.0 \%$ & $64.2 \%$ & $29.3 \%$ \\
\hline PC & $22.0 \%$ & $9.4 \%$ & $29.9 \%$ \\
\hline Both & $23.8 \%$ & $19.8 \%$ & $27.4 \%$ \\
\hline Others & $10.3 \%$ & $6.6 \%$ & $13.4 \%$ \\
\hline
\end{tabular}

Table2: Number of download experiences

\begin{tabular}{|c||c|c|c|}
\hline & All & $\begin{array}{c}\text { High school } \\
\text { students }\end{array}$ & $\begin{array}{c}\text { University } \\
\text { students }\end{array}$ \\
\hline \hline $51 \sim$ & $37.9 \%$ & $38.7 \%$ & $37.8 \%$ \\
\hline $11 \sim 50$ & $25.2 \%$ & $28.3 \%$ & $23.8 \%$ \\
\hline $2 \sim 10$ & $23.8 \%$ & $25.5 \%$ & $23.2 \%$ \\
\hline 1 & $2.5 \%$ & $0.9 \%$ & $1.2 \%$ \\
\hline 0 & $10.6 \%$ & $6.6 \%$ & $14.0 \%$ \\
\hline
\end{tabular}

Table 1 shows the ratios of download media. Many respondents use mobile phones. From Table 1, more than $80 \%$ of high school students and over $50 \%$ of university students use mobile phones, including respondents who use both PCs and mobile phones. Table 2 shows the numbers of download experiences from online music services. Almost $90 \%$ of students have downloaded music.

\subsection{Questionnaire Results}

The questionnaire results are shown in Table 3-a, 3-b. The symbols on the left row correspond to the number of the questions shown in the appendix. 
Table 3-a: Questionnaire results

\begin{tabular}{|c|c|c|c|c|c|}
\hline & $\begin{array}{c}\text { Strongly } \\
\text { agree }\end{array}$ & Agree & Neutral & Disagree & $\begin{array}{l}\text { Strongly } \\
\text { disagree }\end{array}$ \\
\hline F101 & $17.4 \%$ & $34.0 \%$ & $27.0 \%$ & $9.9 \%$ & $11.7 \%$ \\
\hline F102 & $7.1 \%$ & $28.0 \%$ & $35.8 \%$ & $12.4 \%$ & $16.7 \%$ \\
\hline F201 & $8.2 \%$ & $24.1 \%$ & $31.2 \%$ & $17.4 \%$ & $19.1 \%$ \\
\hline F202 & $2.5 \%$ & $15.6 \%$ & $36.2 \%$ & $19.1 \%$ & $26.6 \%$ \\
\hline F301 & $4.6 \%$ & $5.3 \%$ & $24.1 \%$ & $18.1 \%$ & $47.9 \%$ \\
\hline F302 & $2.8 \%$ & $13.5 \%$ & $27.3 \%$ & $20.9 \%$ & $35.5 \%$ \\
\hline F303 & $6.4 \%$ & $14.2 \%$ & $24.5 \%$ & $17.0 \%$ & $37.9 \%$ \\
\hline F401 & $14.9 \%$ & $35.1 \%$ & $24.1 \%$ & $13.5 \%$ & $12.4 \%$ \\
\hline F402 & $24.5 \%$ & $25.2 \%$ & $20.9 \%$ & $14.2 \%$ & $15.2 \%$ \\
\hline F403 & $24.8 \%$ & $29.8 \%$ & $23.4 \%$ & $8.2 \%$ & $13.8 \%$ \\
\hline F404 & $17.4 \%$ & $32.6 \%$ & $26.6 \%$ & $12.4 \%$ & $11.0 \%$ \\
\hline F501 & $8.5 \%$ & $27.7 \%$ & $33.3 \%$ & $13.1 \%$ & $17.4 \%$ \\
\hline F502 & $15.2 \%$ & $20.9 \%$ & $34.0 \%$ & $14.2 \%$ & $15.6 \%$ \\
\hline F601 & $9.2 \%$ & $14.5 \%$ & $27.0 \%$ & $17.4 \%$ & $31.9 \%$ \\
\hline F602 & $11.7 \%$ & $17.4 \%$ & $26.2 \%$ & $14.2 \%$ & $30.5 \%$ \\
\hline F603 & $11.3 \%$ & $13.1 \%$ & $29.1 \%$ & $14.2 \%$ & $32.3 \%$ \\
\hline F701 & $17.0 \%$ & $29.4 \%$ & $22.7 \%$ & $13.5 \%$ & $17.4 \%$ \\
\hline F702 & $11.0 \%$ & $27.3 \%$ & $31.9 \%$ & $16.0 \%$ & $13.8 \%$ \\
\hline F703 & $18.1 \%$ & $22.7 \%$ & $26.6 \%$ & $13.1 \%$ & $19.5 \%$ \\
\hline B101 & $6.0 \%$ & $16.0 \%$ & $24.5 \%$ & $21.3 \%$ & $32.3 \%$ \\
\hline B102 & $27.7 \%$ & $29.4 \%$ & $23.4 \%$ & $9.2 \%$ & $10.3 \%$ \\
\hline C101 & $4.3 \%$ & $13.1 \%$ & $42.6 \%$ & $21.3 \%$ & $18.8 \%$ \\
\hline $\mathrm{C} 102$ & $13.5 \%$ & $22.3 \%$ & $41.1 \%$ & $13.8 \%$ & $9.2 \%$ \\
\hline A101 & $48.6 \%$ & $23.0 \%$ & $14.2 \%$ & $5.7 \%$ & $8.5 \%$ \\
\hline
\end{tabular}

The results of Information questions reveal that many students don't think information by e-mail is very important. Furthermore, information by radio is not important because students do not usually listen to radio. Such information from Internet as web logs and web pages is relatively important. Direct word-of-mouth is more important than word-of-mouth by Internet. The most important information comes from TV; clearly, students are greatly influenced by TV.

As the results of "Brand recognition" questions, students pay much more attention to the musicians than delivery providers. Since consumers cannot directly examine the products of online shopping, it is often asserted that the reliability of the online stores is very important. However, with online music services, consumers can listen to trial songs as products, providing them a change to examine products almost directly. Therefore, consumers care about songs as products, but they have little concern about the reliability of providers.

The "Confidence" results for indirect purchases suggest that consumers do not have confidence that they will be satisfied with products and providers. Therefore, many respondents answered "Neutral." 
Table 3-b: Questionnaire results

\begin{tabular}{|c|c|c|c|c|c|}
\hline & $\begin{array}{c}\text { Strongly } \\
\text { agree }\end{array}$ & Agree & Neutral & Disagree & $\begin{array}{l}\text { Strongly } \\
\text { disagree }\end{array}$ \\
\hline $\mathbf{A 1 0 2}$ & $44.3 \%$ & $17.7 \%$ & $14.9 \%$ & $8.9 \%$ & $14.2 \%$ \\
\hline A201 & $58.5 \%$ & $22.0 \%$ & $11.7 \%$ & $4.3 \%$ & $3.5 \%$ \\
\hline A202 & $21.6 \%$ & $19.1 \%$ & $27.0 \%$ & $17.4 \%$ & $14.9 \%$ \\
\hline A203 & $12.1 \%$ & $13.1 \%$ & $18.4 \%$ & $23.8 \%$ & $32.6 \%$ \\
\hline A301 & $56.7 \%$ & $19.5 \%$ & $13.5 \%$ & $4.3 \%$ & $6.0 \%$ \\
\hline A302 & $16.0 \%$ & $12.4 \%$ & $30.9 \%$ & $16.0 \%$ & $24.8 \%$ \\
\hline A303 & $19.9 \%$ & $21.3 \%$ & $27.0 \%$ & $11.3 \%$ & $20.6 \%$ \\
\hline A401 & $41.5 \%$ & $19.1 \%$ & $20.6 \%$ & $8.5 \%$ & $10.3 \%$ \\
\hline I101 & $47.2 \%$ & $25.5 \%$ & $14.5 \%$ & $7.1 \%$ & $5.7 \%$ \\
\hline $\mathrm{I102}$ & $39.4 \%$ & $23.0 \%$ & $25.5 \%$ & $5.3 \%$ & $6.7 \%$ \\
\hline I201 & $7.1 \%$ & $6.4 \%$ & $18.8 \%$ & $23.4 \%$ & $44.3 \%$ \\
\hline I202 & $5.3 \%$ & $5.3 \%$ & $21.3 \%$ & $19.5 \%$ & $48.6 \%$ \\
\hline I301 & $19.9 \%$ & $18.8 \%$ & $24.1 \%$ & $14.2 \%$ & $23.0 \%$ \\
\hline I302 & $31.2 \%$ & $25.5 \%$ & $19.1 \%$ & $9.9 \%$ & $14.2 \%$ \\
\hline I303 & $27.7 \%$ & $22.7 \%$ & $22.3 \%$ & $10.3 \%$ & $17.0 \%$ \\
\hline I304 & $17.0 \%$ & $18.1 \%$ & $28.7 \%$ & $14.9 \%$ & $21.3 \%$ \\
\hline I401 & $14.5 \%$ & $14.9 \%$ & $24.5 \%$ & $18.4 \%$ & $27.7 \%$ \\
\hline I402 & $31.9 \%$ & $19.9 \%$ & $20.6 \%$ & $9.6 \%$ & $18.1 \%$ \\
\hline
\end{tabular}

Regarding questions about "Attitude," consumers are naturally interested in price. Trial services, sound quality, and data size are clearly important. Opinions are divided about accounting systems.

For questions about "Intention," consumers want to repeatedly download and buy songs. Many consumers also want to download new releases or hit songs. Because the price of one song is cheap or because they can be billed for their purchases, the opportunity of income does not equal the opportunity of downloading.

\section{Analysis by Structural Equation Modeling}

We verified Howard's consumer decision model as a hypothesis for the decision making process of online music service users by structural equation modeling with the questionnaire results.

In the questionnaire, each component of the model has several questions. Since "Information" and "Intention" have more questions, we analyzed the factors of these two components to extract the main factors before structural equation modeling. The factor analysis results suggest that "Information" consists of three factors: "TV," "Radio," and "Consumer Generated Media (CGM)." "Intention" consists of two factors: "Popularity" and "Campaign." These factors are latent variables for structural equation modeling. 
"Brand recognition" and "Confidence" are treated as latent variables. The questions about each component are observed variables for the corresponding components. For "Purchase" as a latent variable, the experience of download is an observed variable.



Figure 2: Consumer decision model as analysis result

"Attitude" in the questionnaires consists of nine questions. Since questions about services included in "Intention" are fit for "Attitude" due to the contents, two questions are assigned to "Attitude," but not to "Intention." Therefore "Attitude" consists of 11 questions. Among them, questions about data size and accounting system are not related to other factors and are difficult to explain with questionnaire results. For that reason, "Attitude" consists of two factors: "Sound quality" and "Trial." 
Figure 2 shows the analysis results of structural equation modeling. Table 4 shows the estimated parameters between the latent variables. The following are the fit criteria of this model. The goodness of fit index (GFI) is 0.865 , the comparative fit index (CFI) is 0.912 , and the root mean square error of approximation (RMSEA) is 0.058 . If the GFI and CFI values are 1.0, the model perfectly fits to the data. Empirically, a desirable value is over 0.95 or 0.9 . The RMSEA value is desirable if it is less than 0.05 : if RMSEA is over 0.1, the model is regarded as unfit. The GFI of this analyzed model is a little small and the whole fitness is not very good, but the model is not regarded as unfit.

Compared with Howard's model as a hypothesis, this model does not include the paths from "Brand recognition" to "Attitude." Instead of this path failure, paths were added from "Attitude" to "Purchase," "Brand recognition" to "Purchase" and from "Attitude" to "Intention." Consumers particular about sound quality or who listen to trial versions often will not purchase the song.

Table 4: Parameter estimates

\begin{tabular}{|ccc|c|c|}
\cline { 3 - 5 } \multicolumn{1}{c}{} & & $\begin{array}{c}\text { Parameter } \\
\text { estimate }\end{array}$ & $\begin{array}{c}\text { Significant } \\
\text { level }\end{array}$ \\
\hline Brand recognition & $<---$ & Information & 0.693 & $* * *$ \\
\hline Confidence & $<---$ & Brand recognition & 0.597 & 0.002 \\
\hline Confidence & $<---$ & Information & 0.346 & 0.037 \\
\hline Intention & $<---$ & Information & 1.112 & $* * *$ \\
\hline Intention & $<---$ & Confidence & -0.369 & 0.076 \\
\hline Attitude & $<---$ & Information & 0.829 & $* * *$ \\
\hline TV & $<---$ & Information & 0.777 & \\
\hline Radio & $<---$ & Information & 0.472 & $* * *$ \\
\hline CGM & $<---$ & Information & 0.371 & $* * *$ \\
\hline Purchase & $<---$ & Intention & 0.861 & 0.027 \\
\hline Popularity & $<---$ & Intention & 1 & \\
\hline Trial & $<---$ & Attitude & 0.374 & \\
\hline Sound quality & $<---$ & Attitude & 0.882 & $* * *$ \\
\hline Purchase & $<---$ & Brand recognition & 0.874 & 0.02 \\
\hline Purchase & $<---$ & Attitude & -1.11 & 0.095 \\
\hline Campaign & $<---$ & Intention & 1 & $* * *$ \\
\hline & & & $* * *: 0.001$ significant level
\end{tabular}

The following are the indirect effects from "Information" to "Purchase:"

- By Attitude: -0.92

- By Brand recognition: 0.60

- By Brand recognition and Confidence and Intention: -0.13

- By Confidence and Intention: -0.11

- By Intention: 0.95 
There are negative effects by "Attitude" or "Confidence." The large effect from "Information" to "Intention" can be explained by the many experienced consumers who regard downloading music as a normal thing. Moreover, the positive effect from "Information" to "Purchase" by "Brand recognition" can be explained by simple purchases that are decided as soon as information is acquired. From the above analysis, in online music services, consumers decide to purchase immediately after information acquisition; on the other hand, the close examination of "Attitude" and "Confidence" discourages consumers from buying music.

\section{Conclusion}

This paper described a consumer behavior model for online music services, the most popular online service in Japan. Based on Howard's consumer decision model, we designed a hypothetical model of a consumer decision model for online music services. The proposed hypothetical model was examined with questionnaire data. As a result of analysis, the model slightly differed from the hypothetical model. However, since its fitness is not very good, it must be improved. Moreover, this questionnaire was only given to students, so we need to include different populations.

\section{References}

Martin Evans, Ahmad Jamal, and Gordon Foxall (2006) Consumer Behavior, John Wiley \& Sons.

Sendy Farag, Tim Schwanen, Martin Dijst, and Jan Faber (2007) "Shopping online and/or in-store? A structural equation model of the relationships between e-shopping and in-store shopping," Transportation Research Part A, 41, pp.125-141.

John A. Howard (1989) Buyer Behavior in Marketing Strategy, Prentice Hall.

Chin-Lung Hsu and His-Peng Lu (2004) "Why do people play on-line games? An extended TAM with social influences and flow experience," Information \& Management, 41, pp.853-868.

Internet Association Japan (2006) Internet white paper 2006, Impress.

Internet Association Japan (2005) Internet white paper 2005, Impress.

Rex B. Kline (2005) Principles and Practice of Structural Equation Modeling, The Guilford Press.

Chuanlan Liu (2007) Modeling Consumer Adoption of The Internet as a Shopping Medium, Cambria Press.

Randall E. Schumacker and Richard G. Lomax (2004) A Beginner's Guide to Structural Equation Modeling, Lawrence Erlbaum Associates.

Hung-Pin Shih (2004) "An empirical study on predicting user acceptance of e-shopping on the Web," Information \& Management, 41, pp.351-368. 
Kazuo Watanabe and Kunihiko Iwasaki (2007) "Factors Affecting Consumer Decisions about Purchases at Online Shops and Stores," Proceedings of IEEE CEC/EEE 2007, pp80-87.

White paper (2007) Information and Communications in Japan http://www.johotsusintokei.soumu.go.jp/whitepaper/ja/h19/index.html

\section{Appendix}

\section{[Questions]}

\section{"Information"}

- Direct word-of-mouth

F101: Do you think word-of-mouth information from your friends is important?

F102: Do you think word-of-mouth information from your family is important?

- Word-of mouth by Internet

F201: Do you think the information from web logs or BBS without registration systems is important?

F202: Do you think the information from BBS with registration systems is important?

- E-mail

F301: Do you think direct mail is important?

F302: Do you think the information from e-mails for members only is important?

F303: Do you think the information from fan clubs is important?

- TV

F401: Do you think the information from TV commercials is important?

F402: Do you want to get TV programs theme songs?

F403: Do you think the information in musical TV programs is important?

F404: Do you want to get movie theme songs?

- Magazines

F501: Do you think the advertisements in magazines are important?

F502: Do you think articles about musicians in magazines are important?

- Radio

F601: Do you think the information from radio commercials is important?

F602: Do you think the information from radio music programs is important?

F603: Do you think information about musicians from special radio programs is important?

- Web pages

F701: Do you think the information of hit charts on web pages is important?

F702: Do you think the information from video delivery web sites is important?

F703: Do you think the information in musician web sites is important?

\section{"Brand recognition"}

B101: Do you try to learn a lot about music delivery providers?

B102: Do you try to learn a lot about the musicians whose songs you are downloading?

\section{"Confidence"}


C101: Do you have confidence in the reliability of delivery providers before purchasing?

C102: Do you have confidence that you will be satisfied with a particular musician's songs before downloading?

“Attitude”

- Trial

A101: Do you think a trial service in delivery sites is important?

A102: Even if you know the song, do you listen to a trial of it?

- Sound quality

A201: Do you pay attention to sound quality?

A202: Do you think such alternative versions as live recordings and outtakes are important?

A203: Are you satisfied with the sound quality by which you can judge the song?

- Accounting system

A301: Do you think price is important?

A302: Do you think a monthly fee is a better accounting system?

A303: Do you prefer payment per song as an accounting system?

- Data size

A401: Do you consider the data size of songs?

\section{"Intention"}

- Service

I101: Do you think the possibility of re-download is important?

I102: Do you think the payment method is important?

- Money

I201: When you have extra money, do you want to download a song soon?

I202: On payday, do you want to download a song soon?

- Motivation

I301: Do you want to download seasonable songs?

I302: Do you want to download new releases?

I303: Do you want to download hit songs?

I304: Do you want to download award-winning songs?

- Campaign

I401: If you can get one free song by purchasing of ten as part of a special campaign, do you want to download?

I402: If you can get unlimited songs much for 300 yen (about \$2.7) for a limited time, do you want to download? 